\title{
Prospects of BOT (Build-Operate-Transfer) Projects for Infrastructure Development in Nepal
}

\author{
Santosh Kumar Shrestha \\ Department of Civil Engineering, Pulchowk Campus, Institute of Engineering, Tribhuvan University, Nepal \\ Email: skshrestha@ioe.edu.np
}

\begin{abstract}
Infrastructure development is one of the top priorities in a country's economic progress. Planned and well connected infrastructure services attract foreign direct investments and boost local investments. To meet the present and future demand for infrastructure development, developing and least developed countries like Nepal always face scarcity of their own resources. To mitigate the shortage of the Government's funds for infrastructure developments, the Build-Operate-Transfer (BOT) mode of financing has been a model in many countries. Considering the BOT project successes in Malaysia, Thailand, the Philippines and other countries, and following Khimti-I and the United World Trade Center building, Nepal must seriously consider having more BOT projects. Especially in its urgently needed infrastructure such as Hydropower generation, roads, bridges, telecommunications, water supply, waste disposal, etc.
\end{abstract}

Key Words: Build Operate Transfer, BOT, Public Private Partnership

\section{Introduction}

A principal constraint to growth in many countries is that the Government does not have enough funds to invest in infrastructure projects. Most nations are seeking ways to finance these projects. They look at privatization as a suitable means to fulfill the needs of financial resources. Private sector involvement depends on both the strategic position of government and the attractiveness to private finance. In many cases, the government desires a certain degree of control over the infrastructure facility. An alternative method involves government asking the private sector to design, build and operate the facility for an agreed period and then transfer ownership to the government free of cost. This is the basic idea of Build-Operate-Transfer (BOT). The term BOT was first used on a power plant project by the Turkish Government in the early 1980s.

\section{Basis of the BOT Model}

In a BOT arrangement, the private sector designs and builds the infrastructure, finances its construction and owns, operates and maintains it over a period often as long as 20 to 50 years. This period is referred as the 'concession' period. Then it transfers the facility back to the government. The company receives sufficient revenues during the concession period to: service debt incurred in designing and building the facility, cover its working capital and maintenance costs, repay its equity investors and hopefully provide them a reasonable profit. Such schemes are also referred to as BOO (Build-Own-Operate), BOOT (Build-Own-Operate-Transfer), FBOOT (Finance-Build-Own-Operate-Transfer) or occasionally other acronyms. This mode of financing is also known as public-private-partnership (PPP) because of the joint enterprise between the government and the private sector. When there is no eventual transfer back to government, it is referred to as full privatization. 


\section{Structure of BOT Projects}

In a traditional construction project, owner, contractor and consulting engineer are usually the three parties involved. The BOT mode of financing is a complex arrangement which involves multiple parties and a long list of agreements among them. The major parties involved in a BOT project are:

- Government agency, which grants concession

- Sponsors, generally a joint venture company, who prepare the proposal to finance, construct and operate the project

- Construction contractor, who is responsible to construct the project

- Operation and Maintenance Contractor, who undertakes operation and maintainance of the project for a stipulated time

- Financiers, normally a syndicate of banks or financial institutions who provide loans to the sponsor of the project

- Equity investors, who provide funds through equity participation

- Insurers

- $\quad$ Equipment suppliers

- $\quad$ Engineering and design consultants

- $\quad$ Potentially other parties

Most of the above-mentioned parties will also engage their lawyers, financial advisors and tax advisers. Among various agreements for a BOT project, the followings are most prominent:

- Concession agreement, which grants sponsors the right to invest in the project

- Off-take agreement, by which the Government agency agrees to purchase the output of the infrastructure at agreed price and volume

- Construction Contract, which is typically a turnkey design-and-construct fixed price contract

- Operation and Maintenance agreement, which is usually a long term contract

- Financing agreements

- Shareholders agreement

- Design agreement

- Equipment supply agreements

- $\quad$ Fuel and Water supply agreements

- Other Service agreements 


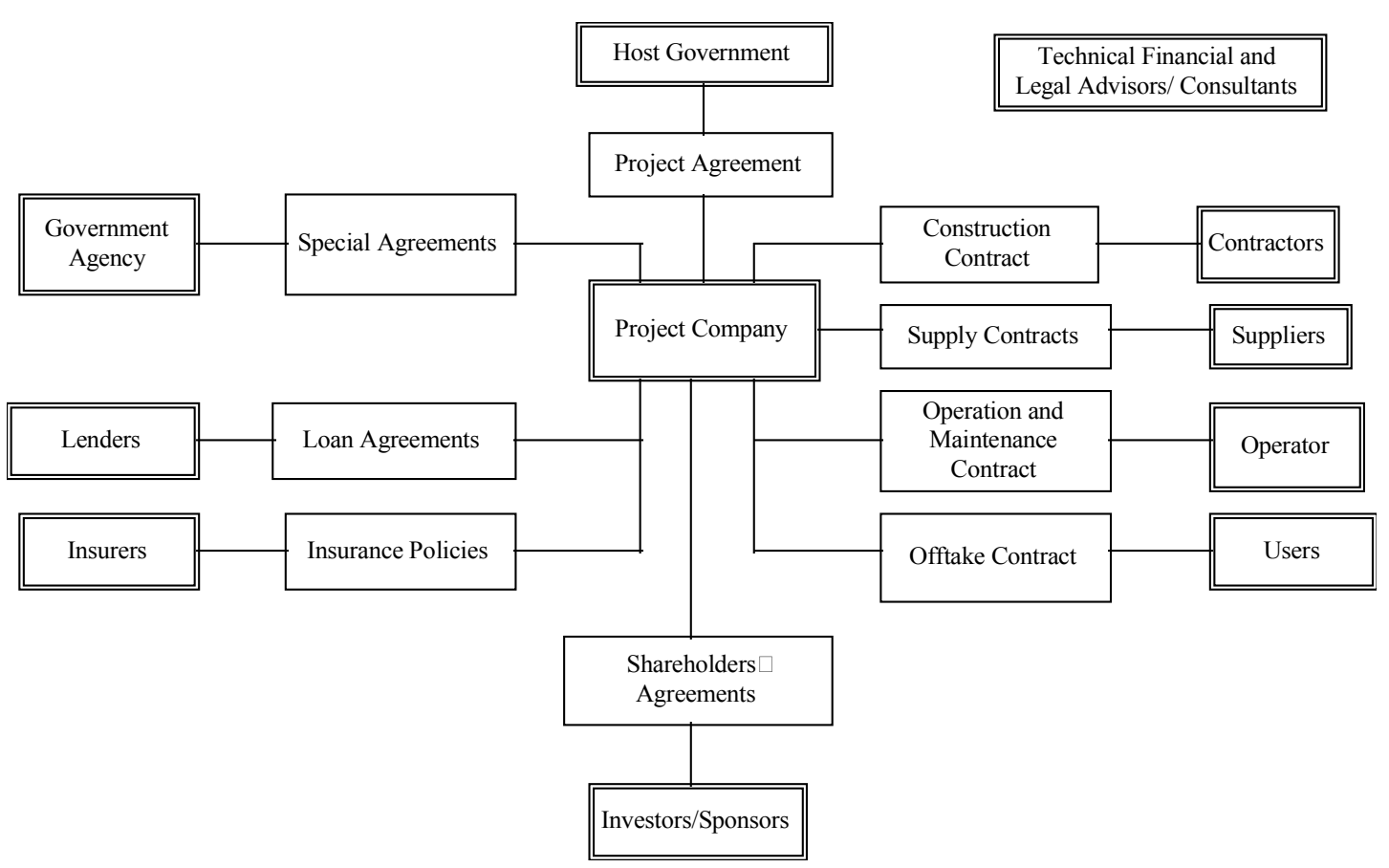

Figure 1: BOT model Typical Contractual Structure

Source: McCarthy and Tiong (1991).

\section{Development of BOT Projects}

Private investments in public infrastructure can be traced back to 18th century examples of concession contracts to supply drinking water in Paris and 19th century examples such as the Suez Canal and Trans-Siberian Railway. This trend continued with the construction of canals, turnpikes and railroads in Europe, The Americas and Japan. In modern Asian countries, Malaysia has shown a tremendous success of BOT projects developing infrastructure which contributed economic growth. Malaysia has undertaken over 40 BOT projects, 9 of which have been completed and are in operation. Among the most successful BOT projects in Malaysia are Penang Bridge, the Shah Alam Expressway and an 848 kilometer long North-South Expressway,. The Malaysian success in BOT projects has been followed by Thailand, Indonesia, Hong Kong, the Philippines and other countries. Five of 15 BOT projects undertaken by Thailand are already open for use. Indonesia has undertaken over 35 projects, 2 of which have been already completed. Both India and the Philippines have undertaken 15 BOT projects each. The Philippines has solved its power crisis by pioneering a BOT arrangement which opened up power generation to foreign investors. Currently, investors from Japan, Hong Kong, America, and Europe are developing new generation capacity in excess of 6,000 MW. This has relieved Manila of the daily eight-hour brownout experienced two years ago.

The concept of BOT infrastructure projects was incorporated in Nepal's planing document as early as 1992. The Eighth Development Plan (1992-97) envisioned private sector participation in viable infrastructure projects, like the proposed Hetauda-Kathmandu tunnel and other roads, on the basis of BOOT. In the Ninth Development Plan (1997-2002), PPP in hydro-power 
development was encouraged, especially with the intent of fostering confidence in the private sector by reducing administrative and procedural rigidities. The Tenth Development Plan (2002 -2007) adopted the policy of promoting private sector participation in the construction and maintenance of the road network. It included the necessary policy and legal reforms as well as improved the facilitative and regulatory role of the government. To attract the private sector in BOT schemes, necessary documentation related to the concession agreements, guidelines, technical specifications, and feasibility studies were arranged by establishing a privatization cell in the Ministry of Physical Planning. Using the BOT model in FY 2005/06, investments in ropeways and railways, including one connecting the Kathmandu Valley with the Terai, were encouraged.

\section{BOT Specific Government Act}

Under the act relating to private sector investment in the construction and operation of the infrastructure, which came into operation August 12, 2006, the Government can invite expressions of interest from concerned parties for the implementation of any project exceeding 20 Million NPR. For implementation, public notice inviting proposals approved parties is made. The proposal is selected within 60 days, on the basis of the economic strength, technical capacity, environmental study, royalty paid to the Government, the proposed amount that the consumers would pay in the project implementation process, and any other specified details. Permission to perform a detailed feasibility study can also be given to an interested party. In specific cases, projects can also be implemented through the negotiations.

The Government signs a letter of understanding with the selected party and the party must then submit project details within the time specified. The Government then enters into an agreement with the party. The terms and conditions including other implementation details regarding the project are included in the agreement. The party has to submit 0.5 percent of the total project cost as the performance bond. After the agreement, the party will be provided a letter of permission to implement the project. The validity of the letter of permission will not exceed 30 years. During the period of the project, the project and its properties will not be nationalized.

The Act has also states that priority projects can be implemented under joint investments between Government and the private sector, with the condition that the Government's share will not exceed 25 percent of the total project cost.

\section{Future Prospects}

Nepal has a short history of previously implemented PPP projects. When Himal Power Limited made an agreement with HMGN to construct the 60MW Khimti-I hydropower plant with private sector funding, it was the first ever "BOOT" project of this type. United Builders Pvt. Ltd. made an agreement with Tribhuvan University to construct a business complex, the United World Trade Center (UWTC), making it an important project under the BOT model. The concession period for Khimti-I and the UWTC are 50 and 30 years, respectively. 


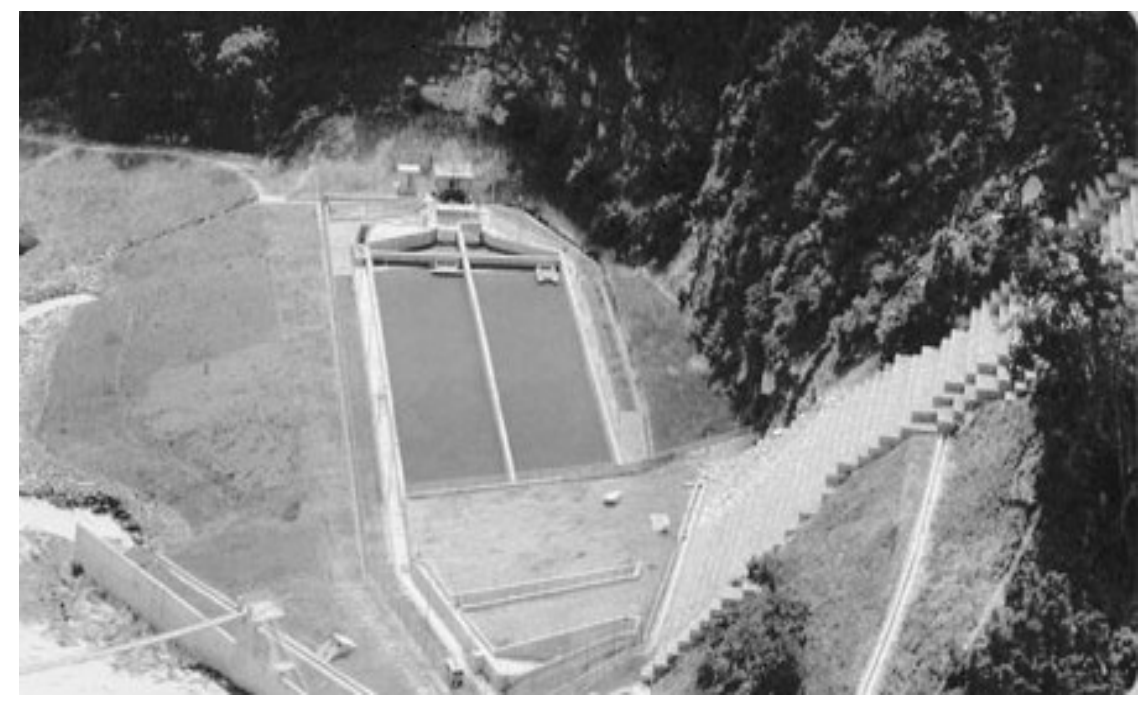

Figure 2: Khimti-I Hydro-Power Project

With the larger success of BOT other countries, and following the Khimti-I and UWTC example, Nepal must seriously consider having more BOT projects in its urgently needed infrastructure development. Hydropower generation, roads, bridges, telecommunications, water supply and waste disposal are all ideal candidates for BOT projects. The construction of the proposed Hetauda-Kathmandu tunnel and other roads can be constructed on the basis of the BOT model. Similarly, BOT arrangements may minimize traffic congestion in Kathmandu with construction of elevated roads, bypass roads, and subways. Following the Philippines' example of BOT arrangements in power generation, Nepal can solve its loadshedding crisis. Extending land-line telephone connections to all Nepali homes and mobile phones to every person may be achieved through a BOT model of investment in telecommunications.

Given the desire of the Government of Nepal to attract foreign direct investment and the enormous need for infrastructure in the country, the BOT model of investment can play a significant role in meeting both the demands. However, the success of BOT projects would depend on:

- Improvement of the country's legal, political and institutional framework for BOT projects

- Capacity building within the Government to deal with BOT projects

- Negotiation skills of the Government with various parties involved

Most importantly, the demonstration of an attractive and conducive investment environment with rule of law, transparency and accountability. 